\title{
Potensi Pemanfaatan Hasil Pemeriksaan Berkala Bangunan Gedung dalam Penentuan Depresiasi Harga Bangunan Gedung Eksisting
}

\author{
Mochamad Hilmy, Herry Prabowo, \& Yudhiarma \\ Program Studi Arsitektur Bangunan Gedung, Jurusan Teknik Arsitektur, \\ Politeknik Negeri Pontianak, Jalan Ahmad Yani, Pontianak \\ Email: mhilmys@gmail.com
}

\begin{abstract}
Over time, buildings are used to experience a decline in the physical quality of architectural, structural, mechanical and electrical components. To ensure its safety and functioning, periodic inspections of the building are required. The periodic technical inspection of buildings has been regulated in the Minister of Public Works Regulation No.16 / PRT / M / 2010. The results of the building inspection provide an overview of the physical condition and function of the building in detail and itemized by involving experts in building technical reviewers. The results of this examination show how much the percentage of physical degradation and function of the building under review has the potential to be used in assessing the price of existing buildings from an economic perspective. Thus the depreciation of building prices can be estimated. Depreciation value is a reduction in the value of fixed assets as a result of being used by the owner. This depreciation parameter is needed in an assessment of a property which is increasingly felt to be needed in various economic and development activities, including for loan guarantees, asset management, and appraisal for land acquisition for the purpose of building public facilities. The calculation of building prices that is carried out shows that the results of periodic inspections of buildings can be used to determine the depreciation of the price of the buildings under review.
\end{abstract}

Keyword: buildings, periodic building inspection, depreciation of building prices.

\begin{abstract}
Abstrak: Bangunan gedung seiring waktu pemanfaatannya mengalami penurunan kualitas fisik komponen arsitektural, struktural, mekanikal, dan elektrikal. Untuk menjamin keamanan dan keberfungsiannya diperlukan pemeriksaan berkala bangunan gedung. Teknis pemeriksaan berkala bangunan gedung telah diatur dalam Permen PU No.16/PRT/M/2010. Hasil pemeriksaan bangunan gedung memberikan gambaran mengenai kondisi fisik dan fungsi bangunan gedung secara rinci dan detail dengan melibatkan tenaga ahli pengkaji teknis bangunan gedung. Hasil pemeriksaan ini menunjukkan seberapa besar persentase degradasi fisik dan fungsi bangunan yang ditinjau sehingga berpotensi pula untuk dimanfaatkan dalam memberikan penilaian harga banguna gedung eksisting dari sisi ekonomis. Dengan demikian depresiasi harga bangunan dapat diperkirakan. Nilai depresiasi merupakan pengurangan nilai harta tetap akibat dimanfaatkan oleh pemiliknya. Parameter depresiasi ini diperlukan dalam penilaian terhadap suatu properti yang semakin terasa diperlukan dalam beragam kegiatan perekonomian dan pembangunan antara lain untuk jaminan pinjaman, pengelolaan aset, serta penilaian untuk pengadaan tanah dengan tujuan untuk pembangunan fasilitas umum. Perhitungan harga bangunan gedung yang dilakukan menunjukkan bahwa hasil pemeriksaan berkala bangunan gedung dapat dimanfaatkan untuk menentukan depresiasi harga bangunan gedung yang ditinjau.
\end{abstract}

Kata Kunci: bangunan gedung, pemeriksaan berkala bangunan, depresiasi harga bangunan

\section{PERAWATAN BANGUNAN GEDUNG}

Bangunan gedung merupakan karya arsitektur yang ditujukan untuk mewadahi aktivitas manusia. Keselamatan bangunan merupakan syarat mutlak keberlangsungan penggunaan sebuah bangunan gedung. Selama 
digunakan, bangunan pasti akan mengalami penurunan kualitas, baik secara fisik maupun fungsi. Untuk memperpanjang kelaikan layan bangunan gedung, perlu dilakukan perawatan, namun biaya perawatan tidak pernah diperhitungkan di awal perencanaan bangunan gedung. Guna membuat penjaminan tentang pelaksanaan kegiatan pemeliharaan dan perawatan bangunan gedung ini berjalan dengan baik maka Kementerian Pekerjaan Umum mengeluarkan Pedoman Teknis Pemeriksaan Berkala Bangunan Gedung melalui Permen PU No.16/PRT/M/2010. Pemeriksaan berkala bangunan gedung perlu dilakukan untuk memberikan jaminan kehandalan seluruh atau sebagian bangunan gedung, komponen, bahan bangunan, dan/ atau prasarana dan sarananya dalam tenggang waktu tertentu guna menyatakan kelaikan fungsi bangunan gedung (PU, 2010). Pemeriksaan bangunan gedung ini penting untuk melihat dalam memberikan suatu dasar pertimbangan bagi penyusutan (depresiasi) harga bangunan gedung eksisting. Nilai penyusutan merupakan salah satu komponen yang digunakan dalam estimasi nilai pasar suatu properti.Tujuan dari penelitian ini adalah guna menegtahui seberapa potensi perhitungan pemeriksaan bangunan gedung terhadap nilai depresiasinya. Diharapkan hasil dari pengkajian ini menjadi bahan pertimbangan bagi pemilik bangunan gedung dan instansi yang berwenang untuk selalu melakukan pemeriksaan berkala secara rutin.

\section{CARA MENENTUKAN PENILAIAN DAN}

\section{ESTIMASI DEPRESISI BANGUNAN}

\section{GEDUNG BERDASAR HASIL}

PEMERIKSAAN BERKALA

Pemeriksaan dilakukan $\begin{array}{r}\text { terhadap } \\ \text { komponen-komponen bangunan } \\ \text { gedung }\end{array}$
meliputi aspek arsitektural bangunan gedung,
struktural bangunan gedung, mekanikal bangunan gedung, elektrikal bangunan gedung, dan tata ruang luar (PU, 2010). Pemeriksaan arsitektural bangunan gedung dilakukan dengan pengamatan visual terhadap penampilan bangunan gedung dan kondisi ruang dalam. Pemeriksaan arsitektural dititikberatkan pada pemenuhan terhadap syarat-syarat keselamatan, kesehatan, kenyamanan, serta kemudahan. Pemeriksaan struktural bangunan gedung dilakukan dengan cara pengamatan visual, pemeriksaan mutu bahan, analisis model, maupun uji beban. Pemeriksaan mekanikal bangunan gedung meliputi pemeriksaan terhadap sistem tata udara, sistem transportasi vertikal, sistem plambing dan pompa mekanik, dan sistem sanitasi. Pemeriksaan elektrikal bangunan gedung meliputi pengamanan terhadap bahaya kebakaran, pencegahan dan penanggulangan bahaya petir, dan sistem instalasi listrik dan penerangan. Pemeriksaan tata ruang luar meliputi pemeriksaan terhadap ruang terbuka hijau, sarana dan prasarana sirkulasi mobil dan orang, serta kelengkapan sarana dan prasarana ruang luar.

Seluruh hasil pemeriksaan atas komponen dan elemen bangunan tersebut selanjutnya dicatat dalam daftar simak dan dikumpulkan untuk memperoleh gambaran tingkat kerusakan bangunan gedung. Tahap berikutnya adalah evaluasi hasil pemeriksaan. Gambaran umum mengenai tingkat kerusakan bangunan gedung yang telah diperoleh kemudian disusun rekapitulasi dan ringkasannya (Gambar 1) untuk menentukan laik fungsi bangunan gedung tersebut. Beberapa acuan yang umumnya digunakan dalam penentuan laik fungsi bangunan gedung antara lain: SNI, Persyaratan dan spsesifikasi teknis, Standar produksi yang dikeluarkan oleh pabrik, Laporan hasil pengujian bahan, Manual pemeliharaan/ perawatan bangunan gedung, Riwayat penggunaan peralatan dan 
perlengkapan bangunan gedung.

Estimasi harga bangunan gedung diperhitungkan dengan menggunakan parameter evaluasi hasil pemeriksaan bangunan gedung dan parameter penilaian harga properti. Metode pemeriksaan bangunan gedung mengacu kepada Permen P.U. No.16/PRT/M/2010. Pada saat melakukan penilaian harga properti, harus menggunakan pendekatan nilai atas tanah dan nilai atas bangunan. Penilaian terhadap suatu properti diperlukan dalam kegiatan perekonomian dan pembangunan antara lain sebagai jaminan pinjaman, pegelolaan aset, serta penilaian untuk pengadaan tanah dalam rangka pembangunan fasilitas umum (Lestari, Cahyono, \& Susanto, 2019), (Tama \& Khoirudin, 2017), (Priyatiningsih, Mulyawan, \& Pakpahan, 2018), (Anastasia \& Tandano, 2014), (Zainuri \& Utomo, 2014), (Dita \& Putra, 2011). Harga suatu properti dapat diperoleh dengan menggunakan pendekatan perbandingan data pasar, pendekatan biaya, dan pendekatan pendapatan. Pendekatan yang digunakan selanjutnya pada penilaian harga properti adalah pendekatan perbandingan data pasar dan pendekatan biaya. Pendekatan biaya melalui nilai atas tanah dan nilai atas bangunan menggunakan pendekatan perbandingan harga pasar. Penilaian bangunan diperoleh dengan cara mengestimasi biaya bangunan dikurangi dengan depresiasi. Perhitungan nilai bangunan gedung dilakukan dengan pendekatan biaya yang terdiri atas dua komponen utama yaitu biaya material atau hard cost dan upah atau biaya soft cost. Biaya hard cost meliputi biaya komponen utama dan/ atau biaya komponen material bangunan dan/ atau biaya komponen fasilitas bangunan. Pada bagian biaya soft cost terdiri atas jasa konsultan perencana, jasa kontraktor, jasa konsultan pengawasan, PPN dan IMB.

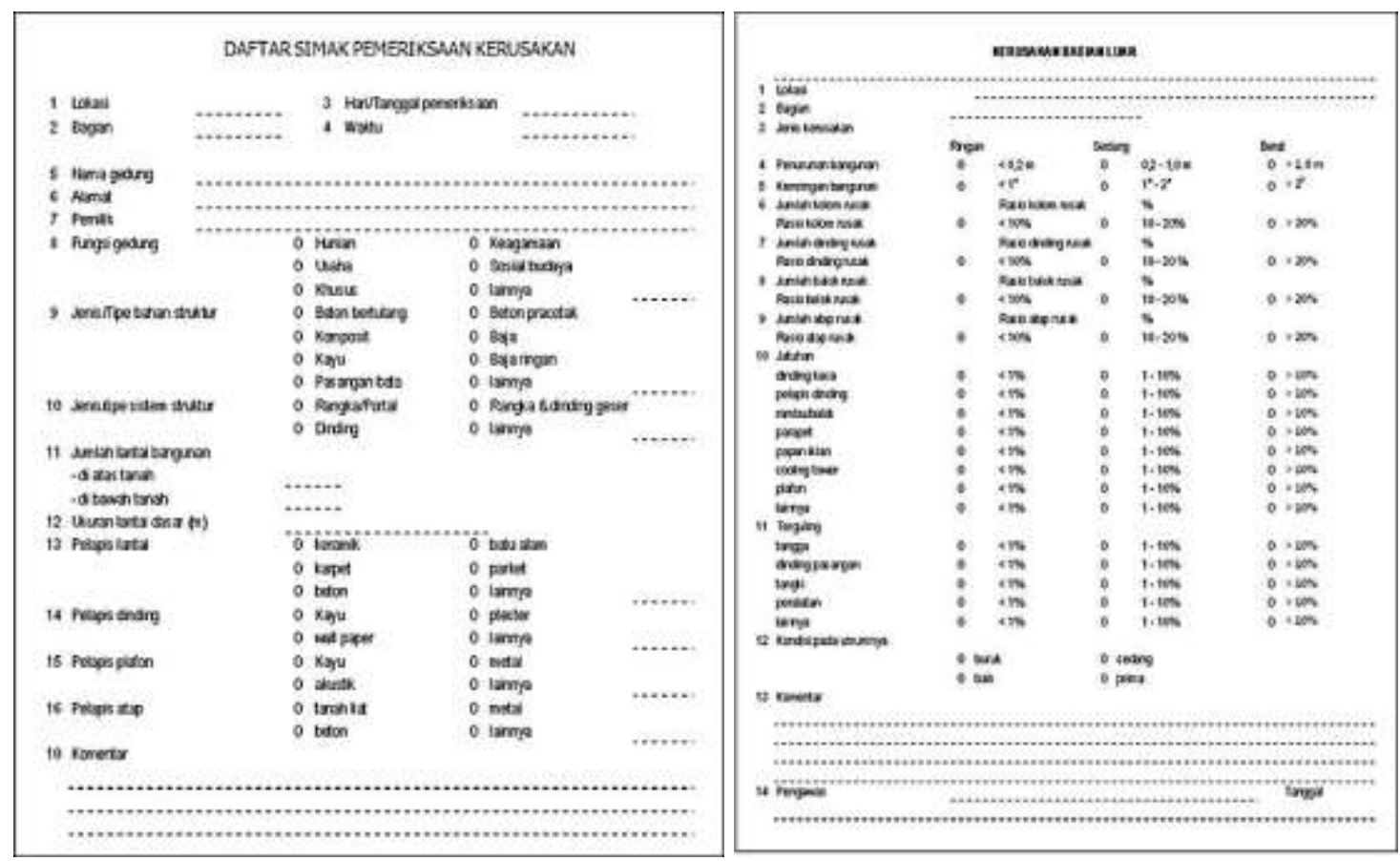

Gambar 1. Daftar dan Rekapitulasi Simak (Sumber: (PU, 2010))

Penyusutan merupakan pengurangan nilai harta tetap akibat dimanfaatkan oleh pemiliknya (Mardjani, Kalangi, \& Lambey,
2015), (Windariyani, 2013), (Ermanuri \& Susanti, 2019), (Sari, 2018). Estimasi depresiasi bangunan gedung dihitung dengan 
memperkirakan penyusutan harga bangunan yang diakibatkan tiga faktor, yaitu: kerusakan fisik bangunan, keusangan fungsi bangunan, dan keusangan ekonomi. Faktor kerusakan fisik bangunan dan keusangan fungsi bangunan diperhitungkan dengan mempertimbangkan evaluasi hasil pemeriksaan berkala bangunan gedung. Keusangan ekonomi disebabkan oleh faktor eksternal bangunan gedung yang berkontribusi dalam menyebabkan turunnya nilai properti.

Tabel 1. Degradasi Bangunan

\begin{tabular}{clc}
\hline No & \multicolumn{1}{c}{ Item Pekerjaan } & $\begin{array}{c}\text { Degradasi } \\
(\mathbf{\%})\end{array}$ \\
\hline 1 & Pekerjaan Persiapan & 0 \\
2 & Pekerjaan Pondasi & 0 \\
3 & Pekerjaan Galian \& & 0 \\
& Timbunan & \\
4 & Pekerjaan Dinding \& & 5 \\
& Plesteran & 5 \\
5 & Pekerjaan Beton Bertulang & 10 \\
6 & Pekerjaan Atap & 10 \\
7 & Pekerjaan Plafond & 5 \\
8 & Pekerjaan Lantai & 5 \\
9 & Pekerjaan PJV & 5 \\
10 & Pekerjaan Pengunci \& & \\
& Penggantung & 11 \\
11 & Pekerjaan Pengecatan & 4 \\
12 & Pekerjaan Instalasi Listrik & 11 \\
13 & Pekerjaan Plambing & 4 \\
14 & Pekerjaan Sanitasi &
\end{tabular}

Tabel 2. Biaya Komponen Konstruksi

\begin{tabular}{rlr}
\hline No & \multicolumn{1}{c}{ Item Pekerjaan } & Biaya (Rp.) \\
\hline 1 & Pek. Persiapan & 55.500 .000 \\
2 & Pek. Pondasi & 246.600 .000 \\
3 & Pek. Galian \& Timbunan & 55.500 .000 \\
4 & Pek. Dinding \& Plesteran & 386.700 .000 \\
5 & Pek. Beton Bertulang & 948.300 .000 \\
6 & Pek. Atap & 101.400 .000 \\
7 & Pek. Plafond & 129.000 .000 \\
8 & Pek. Lantai & 378.300 .000 \\
9 & Pek. PJV & 256.800 .000 \\
10 & Pek. Pengunci \& Penggantung & 33.300 .000 \\
11 & Pek. Pengecatan & 145.500 .000 \\
12 & Pek. Instalasi Listrik & 71.100 .000 \\
13 & Pek. Plambing & 85.500 .000 \\
14 & Pek. Sanitasi & 106.500 .000 \\
& Total & 3.000 .000 .000 \\
\hline
\end{tabular}

Tabel 3. Biaya Total Pembangunan

\begin{tabular}{rlr}
\hline No & \multicolumn{1}{c}{ Item Pekerjaan } & Biaya (Rp.) \\
\hline 1 & Biaya Komponen Konstruksi & 3.000 .000$. \\
2 & Jasa Perencana & 150.000 .000 \\
3 & Jasa Kontraktor & 300.000 .000 \\
4 & Jasa Pengawas & 150.000 .000 \\
& Total & 3.600 .000 .000 \\
\hline
\end{tabular}

Tabel 4. Depresiasi Fisik dan Fungsi

\begin{tabular}{rlrr}
\hline No & Item Pekerjaan & $\begin{array}{c}\text { Depresiasi } \\
\text { (Rp.) }\end{array}$ & \multicolumn{1}{c}{$\begin{array}{c}\text { Nilai } \\
\text { Bangunan } \\
\text { (Rp.) }\end{array}$} \\
\hline 1 & Pek. Persiapan & 0 & 55.500 .000 \\
2 & Pek. Pondasi & 0 & 246.600 .000 \\
3 & Pek. Galian \& & 0 & 55.500 .000 \\
& Timbunan & & \\
4 & Pek. Dinding \& & 19.335 .000 & 367.365 .000 \\
& Plesteran & & \\
5 & Pek. Beton & 47.415 .000 & 900.885 .000 \\
& Bertulang & & \\
6 & Pek. Atap & 101.400 .000 & 91.260 .000 \\
7 & Pek. Plafond & 129.000 .000 & 116.100 .000 \\
8 & Pek. Lantai & 18.915 .000 & 359.385 .000 \\
9 & Pek. PJV & 12.840 .000 & 243.960 .000 \\
10 & Pek. Pengunci \& & 1.665 .000 & 31.635 .000 \\
& Penggantung & & \\
11 & Pek. Pengecatan & 16.005 .000 & 129.495 .000 \\
12 & Pek. Instalasi & 2.844 .000 & 68.256 .000 \\
& Listrik & & \\
13 & Pek. Plambing & 4.275 .000 & 81.225 .000 \\
14 & Pek. Sanitasi & 4.260 .000 & 102.240 .000 \\
& Total & 150.594 .000 & 2.849 .406 .000 \\
\hline
\end{tabular}

Tabel 5. Nilai Properti

\begin{tabular}{clr}
\hline No & \multicolumn{1}{c}{ Item Pekerjaan } & \multicolumn{1}{c}{ Biaya (Rp.) } \\
\hline 1 & Biaya Total Pembangunan & 3.600 .000 .000 \\
\hline 2 & Depresiasi Fisik \& Fungsi (-) & 150.594 .000 \\
3 & Depresiasi Ekonomi (-) & 72.000 .000 \\
\hline 4 & Nilai Tanah (+) & 2.000 .000 .000 \\
& Total & 5.377 .406 .000 \\
\hline
\end{tabular}

\section{HASIL}

Simulasi penilaian harga properti diperoleh dengan cara mempertimbangkan evaluasi hasil pemeriksaan berkala terhadap bangunan gedung yang akan dinilai. Nilai persentase degradasi pada evaluasi tersebut digunakan untuk memperhitungkan besarnya depresiasi bangunan gedung ditinjau dari aspek fisik dan fungsi. Tahapan selanjutnya adalah dalam menentukan harga properti eksisting didapat dengan menghitung biaya total bangunan yang dikurangi dengan depresiasi fisik dan fungsi dari hasil pemeriksaan yang dilaksanakan secara berkala kemudian dikurangi depresiasi ekonomi dan ditambah dengan nilai tanah.

Hasil pemeriksaan berkala bangunan gedung yang meliputi aspek arsitektural bangunan gedung, struktural bangunan gedung, 
mekanikal bangunan gedung, elektrikal bangunan gedung, dan tata ruang luar dikelompokkan dan disesuaikan berdasarkan item pekerjaan konstruksi bangunan. Hasil evaluasi bangunan dinyatakan dalam persentase kerusakan atau degradasi komponen bangunan. Besarnya kerusakan dapat diamati pada tabel 1 .

\section{PEMBAHASAN}

Penilaian harga properti diawali dengan perhitungan biaya hard cost seperti terlihat pada tabel 2. Kemudian dihitung biaya soft cost yang meliputi biaya jasa konsultan perencana, jasa kontraktor, jasa konsultan pengawasan, PPN dan IMB. Biaya jasa konsultan perencana dan pengawas masing-masing diambil sebesar 5\% dari total biaya komponen bangunan. Biaya jasa kontraktor diambil sebesar $10 \%$ dari total biaya komponen bangunan. PPN diambil sebesar 10\% dan IMB diperkirakan sebesar 50 juta rupiah. Biaya bangunan kemudian dihitung dengan menjumlahkan komponen biaya hard cost dengan komponen biaya soft cost (tabel 3).

Depresiasi bangunan gedung eksisiting dihitung berdasarkan evaluasi hasil pemeriksaan berkala bangunan gedung. Besarnya nilai depresiasi akibat kerusakan fisik dan keusangan fungsi diambil dari besarnya persentase degradasi yang terjadi untuk tiap item pekerjaan. Pekerjaan struktur bawah bangunan gedung diasumsikan tidak terjadi degradasi karena tidak mengalami kerusakan seperti misalnya penurunan fondasi. Depresiasi akibat keusangan ekonomi diambil sebesar 2\% dari total biaya bangunan. Simulasi hasil depresiasi bangunan gedung eksisting dapat dilihat pada tabel 4. Setelah nilai depresiasi bangunan diperoleh maka selanjutnya bisa dihitung harga properti eksisting. Hasil perhitungan disajikan pada tabel 5 .

\section{SIMPULAN}

Simulasi penilaian harga properti menunjukkan bahwa hasil pemeriksaan berkala bangunan gedung dapat dimanfaatkan sebagai dasar pertimbangan dalam menentukan nilai depresiasi bangunan dari aspek fisik dan fungsi. Hasil yang pemeriksaan berkala bangunan gedung memberikan gambaran kondisi bangunan gedung eksisiting secara rinci. Degradasi bangunan diestimasi sebesar 5,36\% dengan usia bangunan sekitar 5 tahun dan umur layan rencana 50 tahun. Jika diperlukan, uji dengan peralatan dan instrumen NDT (nondestructive test) lain dapat dilakukan misalnya dengan uji profometer dan UPV (ultrasonic pulse velocity) test untuk mendukung proses pemeriksaan bangunan guna memperoleh hasil pengukuran yang lebih valid dan reliable.

\section{UCAPAN TERIMA KASIH}

Terima kasih diucapkan kepada Politeknik Negeri Pontianak atas dukungan dana dan kesempatannya untuk melakukan pengkajian tentang potensi pemanfaatan hasil pemeriksaan berkala bangunan gedung ini.

\section{DAFTAR PUSTAKA}

Permen PU RI No 16 Tahun 2010. (2010). Pedoman Teknis Pemeriksaan Berkala Bangunan Gedung. Jakarta: Kementerian Pekerjaan Umum Republik Indonesia.

Supriyanto, H. (2014). Penilaian Properti. Jakarta: Kementerian Keuangan Republik Indonesia.

Anastasia, N., \& Tandano, S. C. (2014). Penilaian Apartemen di Surabaya. Jurnal Studi Manajemen, Vol.8 No.1.

Dita, N., \& Putra, P. (2011). Faktor-Faktor Yang Mempengaruhi Perubahan Nilai Tanah Dan Bangunan Pada Suatu Properti. Jurnal Teknik Sipil Kern, Vol. 1 No. 1. 
Ermanuri, E., \& Susanti, E. P. (2019). Penerapan Metode Penyusutan Aktiva Tetap Pada Rumah Sakit Melati Tangerang. Jurnal Lentera Akuntansi, Vol. 4 No.1.

Lestari, V. N., Cahyono, D., \& Susanto, O. A. (2019). Perlunya Penilaian Properti pada Kantor Jasa Penilai Publik. Journal Community Development And Society, Vol. 1 Ed. 1, $20-33$.

Mardjani, A. C., Kalangi, L., \& Lambey, R. (2015). Perhitungan Penyusutan Aset Tetap Menurut Standar Akuntansi Keuangan Danperaturan Perpajakan Pengaruhnya Terhadap Laporan Keuangan Pada Pt. Hutama Karya Manado. Jurnal EMBA, Vol.3 No.1 .

Priyatiningsih, K., Mulyawan, I., \& Pakpahan, R. (2018). Pengelolaan Properti Rukos Bberbasis Pada Kinerja Aset. Difusi, Vol.1, No.1, 20-31.

Sari, D. I. ( 2018). Analisis Depresiasi Aktiva Tetap Metode Garis Lurus dan Jumlah Angka Tahun PT Adira Dinamika. Jurnal Moneter Vol. V No. 1 .

Tama, R. J., \& Khoirudin, R. (2017). Penilaian dengan Metode Land Development Analysis. I-Finance, Vol.1. No 1, 19-30.

Windariyani, F. (2013). Perlakuan Akuntansi Penyusutan Aktiva Tetap dan Pengaruhnya Terhadap Kewajiban Pajak pada PT Synergy Indonesia. Jurnal Akuntansi, Ekonomi dan Manajemen Bisnis, Vol. 1, No. 2, 167-174.

Zainuri, M., \& Utomo, C. (2014). Analisa Nilai Agunan Rumah Tinggal Jl. Gebang Lor No.62 Surabaya. Jurnal Teknik Pomits, Vol. 3, No. 2. 